\title{
Hvordan en gammel kontrakt kan kaste nyt lys over hollændernes skriftsprog på Amager i 1600-tallet
}

\author{
Joost Robbe \\ Aarhus Universitet
}

\begin{abstract}
This article investigates the linguistic characteristics of the written language used by the Dutch community on the Danish island of Amager in the $17^{\text {th }}$ century. It does so on the basis of a hitherto unexamined text, a contract from 1664 between the minister and the inhabitants of the village of Store Magleby. Until now, the written language used by the Dutch community on Amager in the $17^{\text {th }}$-century has been viewed as Low German with a minor Dutch component. However, the text analyzed in this article can be more accurately described as Dutch with a minor Low German component. The article will argue that this apparent discrepancy can be explained by viewing the written language of the Dutch community on Amager as a Low German-Dutch continuum whereby each concrete linguistic expression is dictated by the communicative situation: documents for internal use (i.e. use within the Dutch community) are predominantly Dutch, whereas documents for external use (i.e. use outside the Dutch community) are predominantly Low German.
\end{abstract}

\section{Indledning}

Det er et velkendt faktum, at i perioden 1515-1521 bosatte en større gruppe nederlandske bønder sig på Amager. På opfordring af kong Christian 2. (1513-1523) kom de til øen, hvor de opnåede en høj grad af administrativ og juridisk autonomi. Den nederlandske koloni - med Store Magleby som administrativt centrum - overlevede Christian 2.s afsættelse i 1523 og havde sin egen særlige styreform helt frem til 1817. Denne styreform kaldes for schout-styret, eftersom den såkaldte schout ('oldermand'), der

Ken Ramshøj Christensen, Henrik Jørgensen \& Johanna L. Wood (eds.). 2019.

The Sign of the V-Papers in Honour of Sten Vikner.

Dept. of English, School of Communication \& Culture, Aarhus University, pp. 503-521, doi:10.7146/aul.348.113. (C) The author(s). 
blev valgt på livstid, var den øverste myndighed i byen (Pedersen 1968, 23). ${ }^{1}$

Desuden udviklede de nederlandske kolonister et sprog, som Erik Pontoppidan $(1747,141)$ kaldte for et 'Miskmask af Hollandsk, Plattydsk og Dansk'. Dette sprog betegnes for første gang som 'Amager Hollandsk' af Laurids de Thurah $(1758,18)$. Selvom det ikke mere er muligt at undersøge det 'amagerhollandske' talesprog, så er det dog muligt at undersøge, hvilket skriftsprog de nederlandske kolonister benyttede sig af. Den hollandske koloni havde nemlig en egen 'skriver' til administrative dokumenter, der havde en fast rolle i koloniens retsvæsen (Nicolaisen 1909, 35-36). Retten i Store Magleby var indrettet efter nederlandsk mønster og bestod af 9 mænd, nemlig selve schouten, som var dommer, og skriveren, begge fast ansatte, samt 7 scheppens eller meddomsmænd, der valgtes eller ansattes hvert år at til at stå ved schoutens side. Skriveren var gerne en af byens mænd, som senere indtrådte i schout-embedet (Nicolaisen 1909, 35-36). Denne tradition blev holdt vedlige til det allersidste: Dirch Cornelissen (1743-1817) var byens skriver fra 1780 til 1797 og schout fra 1797 til 1817, hvorefter schout-embedet ophævedes (Riber 1975, 66).

Indtil videre er kun få af amagerhollændernes tekster blevet udforsket, og disse giver anledning til den antagelse, at kolonisternes skriftsprog $\mathrm{i}$ 1600-tallet var hovedsageligt nedertysk med nogle få nederlandske relikter (Winge 1992, 343). I denne artikel undersøger jeg dog en tekst fra 1664, hvis sprog kan bestemmes som hovedsageligt nederlandsk med en mindre nedertysk andel - altså det modsatte af det, man på grundlag af de andre tekster forventer. Denne modsætning er dog ikke uløselig. Den kan løses ved at forestille sig amagerhollændernes skriftsprog i 1600-tallet som et nederlandsk-nedertysk kontinuum, hvoraf det konkrete udtryk afhænger af den specifikke kommunikative situation: Indadtil - inden for Store Magleby - brugte man et sprog, der var hovedsageligt nederlandsk, medens man udadtil - i forhold til omverdenen - anvendte et sprog, der var hovedsageligt nedertysk.

Først præsenterer jeg de enkelte tekster, der hidtil er blevet udforsket. Derefter introducerer jeg den tekst, der står centralt i denne artikel, nemlig en kontrakt mellem præsten og beboerne i Store Magleby fra 1664. Ved en grundig sproglig analyse vil jeg påvise, at sproget i denne tekst

1 Jeg oversætter schout med 'oldermand' i overensstemmelse med Encyklopcedien (artiklen Amager, bd. 1). Ordet schout har i øvrigt selvstændig artikel i $O D S$, og sættes dér i forbindelse med det nedertyske skultus. Både schout og skultus nævnes også i Skautrup $1947,138 f$. 
- imod alle forventninger - faktisk kan bestemmes som hovedsageligt nederlandsk med en mindre nedertysk andel. Til sidst sammenligner jeg resultaterne af den sproglige analyse af denne tekst med resultaterne af den sproglige analyse af de andre tekster og introducerer hypotesen om amagerhollændernes skriftsprog i 1600-tallet som et nederlandsknedertysk kontinuum.

\section{En vedtagt og to indskrifter}

Pontoppidan $(1747,141)$ opfattede de nederlandske kolonisters sprog som en kuriositet og ville meget gerne give sit publikum mulighed for at stifte bekendtskab med det. Til det formål henviste han først og fremmest til den i 1715 udgivne Psalme-Bog og en ukendt udgave af den nederlandske menigheds Catechismus. ${ }^{2}$ Disse bøger blev til i Danmark sidst i 1600-tallet (Winge 1992, 341). Forfatteren er Thomas Harder (1645-1691), der var præst i Store Magleby i perioden 1682-1691. Imidlertid virker sproget i Psalme-Bog og Catechismus som rent nedertysk (Winge 1992, 341). ${ }^{3}$ Derudover gav Pontoppidan en ekstra prøve, nemlig sin egen transskription af en vedtægt mellem Store Magleby og nabobyen Dragør fra 3. december 1663 (Pontoppidan 1747, 138-9; se også Nicolaisen 1909, 205-207 og Winge 1992, 341-342). Denne transskription på lidt under 500 ord (se bilag 1) blev genoptrykt af de Thurah (1758, 23-24), således at - med de Thurahs ord - 'Liebhaverne deraf kan erfare deres [dvs. kolonisternes] nu brugelige Sprog' $(1758,18)$. Ordet 'nu' skal forstås ret udstrakt, eftersom de Thurah skrev næsten et århundrede efter den originale teksts tilblivelse. Desuden skal man være opmærksom på ikke at sammenblande tale- og skriftsprog. Sproget i vedtægten er ikke nødvendigvis det sprog, kolonisterne faktisk talte.

Pontoppidans transskription af vedtægten blev underkastet en detaljeret sproglig analyse af Vibeke Winge med hjælp fra Robert Peters (Winge 1992, 342-343). Winge bestemte teksten som hovedsageligt nedertysk (Winge 1992, 342). Nedertyske træk findes ifølge Winge især i basisordforrådet inden for pronominer, konjunktioner, adverbier og verber. Højtyske træk synes at indtage andenpladsen. De danske træk er af ortografisk art og begrænser sig til $\langle$ nd $>$ og $\langle a a>$ i Indvaaners og $<\mathfrak{x}>$ i Vorcelders, Prcester og (Krigs) Woesen. Endelig findes i teksten også enkelte nederlandske

2 Denne Catechismus er bevaret i udgaver fra 1734 og 1735; desuden kendes til nu tabte udgaver fra 1685 og 1709 (Appel 2001, 173).

3 En undersøgelse af, om der også findes spor af nederlandsk eller dansk i teksterne, venter jeg at kunne gennemføre i nærmeste fremtid. 
'relikter' (Winge 1992, 343). Disse omfatter det nederlandske substantiv grond 'jord' og fagudtryk som schout og briggeld 'bropenge' (jf. WNT, brêge) samt den bestemte artikel i neutrum (h)et 'det' og konjunktionen ende 'og' (ved siden af nedertysk unde og højtysk und). Vedtægtens sprog er således næsten gennemgående nedertysk med kun få nederlandske træk (Winge 1992, 343).

Winge (1992, 343) nævner også en anden tekst fra 1600-tallet, nemlig følgende indskrift i kirken i Store Magleby, der står på en mindetavle på kirkens nordmur:

Anno 1611 hebben deisse keirsspels menn laten deisse kerck verbeteren wp eirre eigene wnkosste.

I moderne dansk oversættelse: 'I året 1611 lod dette sogns mænd denne kirke udbedre for egen regning'.

Denne sætning kan bestemmes som danskpåvirket nedertysk, med fuldstændig typisk slut-1500-tals/1600-tals ortografi: $<i>$ brugt som længdemarkør efter $\langle e\rangle$, dobbeltkonsonanter så som $\langle n n>$ samt $\langle w\rangle$ for $\langle u\rangle$. Den danske påvirkning ses ved den foranstillede genitiv deisse keirsspels samt ved det danske substantiv wnkosste (jf. unkost i Kalkar 1892-1901 IV). ${ }^{4}$

Det samme kan siges om en anden indskrift, som schout Cornelis Cornelissen lod anbringe i kirken i Store Magleby i 1731 (Rasmussen 1968, 50; Winge 1992, 344):

Anno 1731 is dese Kerck omgebouwet up unse Egen Bekostning. Dit selve Jahr als den 6 Juny is Koning Christian de 6 gekroont. Cornelis Cornelissen Skoudt.

I moderne dansk oversættelse: 'I året 1731 den 6. juni blev denne kirke ombygget for vores egen regning. Samme år blev kong Christian 6 . kronet. Oldermand Cornelis Cornelissen.'

Også i dette tilfælde er der - bortset fra det nederlandske udtryk Skoudt tale om danskpåvirket nedertysk, medens den danske påvirkning ses ved suffikset -ning i bekostning.

4 Se også Winge 1992, 344 og Rasmussen 1968, 49-50. Rasmussens transskription er ikke helt korrekt, idet keirsspelsmenn ikke er ét, men to ord, så at keirsspels skal betragtes som foranstillet genitiv. 
På grund af vedtægten og de to ovenfor anførte indskrifter kan man således fristes til at konkludere, at kolonisternes skriftsprog i 1600-tallet først og fremmest var nedertysk med kun en meget ringe nederlandsk indflydelse.

\section{En kontrakt}

I Store Maglebys Liber daticus 1738-89 (København, Rigsarkivet, nr. EC-043, side 5) findes en kopi af en kontrakt fra 1664 mellem præsten i Store Magleby, Jørgen Harder (1608-1682) og byens borgere om kirkens udredning af præsternes kongelige skatter, navnlig ekstraskatter samt kvæg-, tiende- eller kornskat. Denne kopi fra 1700-tallet blev affattet af Jørgen Gottfriedsen Røbel (1704-1760), der var præst i Store Magleby fra 1735 til sin død i 1760. Røbel var født i Kalundborg som søn af kirurgen Gottfried Røbel og dennes hustru Margrethe Røbel, født Weihe. Han blev student i København i 1722 (Rasmussen 1981, 105). Kopien findes også trykt i Nicolaisen $(1915,354-5)$ og - delvist - i Winge (2001, 302), dog med mange transskriptionsfejl og uden sproglig analyse.

Helt konkret er kontrakten opstillet mellem præsten Jørgen Harder som den ene og Dirch Cornelissen (schout 1652-1666) som den anden part. Nedenfor følger min transskription og oversættelse til moderne dansk:

Anno 1664 d. 24. Junij is tusschen den Preester en den Schout Dirch Cornelissen en syne drie jaars Schæpen in voller en vaster contract gesloten worden om den Præster Schatt; wanneer namelyk Syne koninglyke Majestet den Præstern im Lande Schatt opleydt, so sal de Kerke nae oude gebruyk ende gewoonte alle schatting ('t zy hooftschatt, geldschatt, Madtschatt, Ruyterschatt, Kooper, Tin, edder Kornschatt, wat name 't ook hebben mag) voor den Præster uthleggen, doch subsidien gelder, so den armen Preestern tot hulpe gegeven worden, sal de Præster sulvest erleggen. En terwyl even in desen jaer stryd was wegens der Princessinnen Stuyr, daer de Kerke van haere Tienden sowel geven moeste als de Preester, is 't so veraccordeert ende bewilliget, dat wanneer de Kerke van haeren egen Tienden mede schatten sal, so sal se dem Præster niet meer als de halve part tot synen schatt tot hulpe komen, en de Præster sal selven de andere halve part van synen schatt geven als te sien uyt der Kerken rekeninge Anno 1665 en Anno 1667. Insgelyken is de Kerke nae ouden gebruyk schuldig 
dem Preester een Vrywoonhuys en Residence te verschaffen en jaerlyks te onderhouden; de oorsake van dese twee laeste posten zyn dese: Terwyl de Preester aan dese plaetse niet heeft akker of enge by synen deenste, insgelyken geene Tiende vam Veh (als süst im gantzem Ryke dem Preestern nae der ordinantie gebeurt) so is 't hem daerintegen van de Gemeente van allem ouden tyd her belooft en versproken worden Vrywoonhuys en uthlegginge aller koninglyke schatting voor hem.

Tot getuygenisse der Waerheyt.

M. Jürgen Harder

Richtige copie uyt het Kerken-Rekeninge-boek

test [e] J.G. Röbel

I året 1664 den 24. juni er der mellem præsten og oldermand Dirch Cornelissen og hans 'tre års meddomsmænd' [se nedenfor, JR] i fuld og fast kontrakt blevet truffet en beslutning om præsteskatten. Når nemlig Hans Kongelige Majestæt pålægger præsterne i landet en beskatning, så skal kirken efter gammel skik og brug udlægge al skat (enten kopskat, rentepengeskat, madskat, rytterskat, kobber-, tin-, eller kornskat, hvad det så end måtte hedde) for præsten, men bistandspenge, der gives til de fattige præster, skal præsten selv betale afgift af. Og fordi der netop i år har været diskussion om 'prinsessestyren' [se nedenfor, JR], til hvilken både kirken og præsten skulle afdrage af deres tiende, blev der aftalt og bekræftet, at når kirken af sin tiende skal medbetale, så skal kirken ikke hjælpe præsten mere end med halvdelen af hans præsteskat, og præsten skal selv give den anden halvdel, og det vil fremgå af kirkeregnskabet fra årene 1665 og 1667. Ligeledes bør kirken efter gammel skik give præsten frit hus og bopæl og årligt underholde denne. Årsagerne til disse sidste to poster er følgende: Fordi præsten her på stedet hverken har ager eller eng for sin embedsgerning eller tiende for kvæg (som dette sker for præsterne i hele riget ifølge kongeligt dekret), så er ham for længe siden blevet lovet af kommunen et frit hus og betaling af al kongelig skat for ham.

Som vidnesbyrd for sandheden

M. Jürgen Harder

Sandfærdig kopi fra kirkeregnskabsbogen

Test[e] J.G. Röbel 
Det mærkelige udtryk 'tre års meddomsmænd' kan forklares ved, at, når større eller vigtigere kommunale afgørelser forelå (som i vores tilfælde), toges også de to foregående års scheppens med på råd (Nicolaisen 1909, 35-36). Udtrykket 'prinsessestyren' relaterer sig til rigets skattevæsen. Her er der nemlig tale om en særlig skat, som skulle betale prinsesse Frederikke Amalies (1649-1704) medgift, da hun i 1667 blev formælet med Christian Albert (1641-1695), hertug af Slesvig-Holsten-Gottorp (jf. Prinsessestyr i $O D S$ ). Det kongelige dekret, der henvises til, er sandsynligvis kirkeordinansen fra 1539 (jf. Skautrup 1947, 139; Kirkeordinansen i Encyklopcedien, bd. 10).

Kopien omfatter 270 ord i latinsk håndskrift. I betragtning af det korte tidsinterval mellem vedtægten og kontrakten (næppe mere end syv måneder) må man undres over de store sproglige forskelle. Den eneste fællesnævner mellem begge tekster synes at være, at de danske træk ikke er særlig udprægede. I kontrakten omfatter disse kun ortografien Schœepen og Prcester med $\langle\mathfrak{x}\rangle$ (ud over Preester med $<e e\rangle$ ) og de leksikale lån Madtschatt 'mad(t)skat' (Kalkar 1892-1901, III, 3-4) - dog med den nederlandsk-tyske ortografi $<s c h>-$ og enge i udtrykket akker of enge.

Ellers er de indbyrdes forskelle meget store. I modsætning til vedtægten er kontrakten affattet på et sprog, der er gennemgående nederlandsk med hensyn til pronominerne, konjunktioner, adverbier og verber, medens vedtægten - som sagt - netop på disse områder er nedertysk. Også for den nutidige læser af moderne nederlandsk kan kontraktens sprog stadigvæk gå for at være et (omend lidt besynderligt) nederlandsk. Dertil kommer, at de ord, denne moderne læser måtte opfatte som 'tyske', mest nok er helt normale nederlandske ord i historisk forstand. Et godt eksempel derpå er adverbiet her i udtrykket van allem ouden tyd her 'for længe siden', der ikke var ualmindeligt i ældre nederlandsk, men som nu er forsvundet ud af sproget (jf. WNT, her ${ }^{2}$ ).

Specifik nedertysk ortografi ses dog ved præfikset $u$ th 'ud' i verbet uthleggen 'betale, udrede' og det af dette verbum afledte substantiv uthlegginge 'betaling, udredning'. Dette gælder i øvrigt kun for præfikset; præpositionen uyt 'ud' staves konsekvent som på nederlandsk (jf. den moderne nederlandske stavemåde uit). Dertil kommer stavemåden af substantiverne Preester 'præst' og deenst 'embede'. Denne ortografi vidner om en nedertysk - i modsætning til nederlandsk og højtysk - lydudvikling fra senfællesgermansk *iu-over oldsaksisk io - til den middelnedertyske monoftong $\hat{e}^{4}$, hvorimod senfællesgermansk *eo har udviklet sig til den middelnederlandske og middelhøjtyske diftong ie (Van Loey 1970, §§ 
67, 81-82). Samme ortografi ses i øvrigt også i vedtægten ved samme substantiv Denst 'embede' og pronominet nemand 'ingen'. Rent nedertyske ord i teksten er pronominet sulvest 'selv' (ved siden af det nederlandske selve( $(n)$ ), konjunktionen edder 'eller' (ved siden af det nederlandske of) og adverbiet even (i betydningen 'netop').

Specifik højtysk ortografi ses ved substantivet Veh 'kvæg' og adjektivet gantzem 'hel' med henholdsvis $\langle h\rangle$ og $\langle t z\rangle$, og i det hele taget ved, at substantiverne gennemgående, men ingenlunde konsekvent, skrives med stort begyndelsesbogstav.

De andre tyske træk kan ikke bestemmes nærmere som enten nedereller højtyske. Ortografien med identisk dobbeltkonsonant i udlyd i substantivet Schatt er tysk og ikke nederlandsk (i modsætning til stavningen af f.eks. verbalformen opleydt 'pålægger', der ender på to forskellige konsonanttegn). Verbet erleggen 'erlægge' er oprindeligt (høj)tysk, men sandsynligvis hentet fra det danske kancellisprog. Det samme gælder Majestet og (Princessinnen) Stuyr.

Med hensyn til substantivernes pluralisdannelse springer den tyske pluralisform gelder 'penge' som andet led i sammensætningen subsidien gelder 'bistandspenge' i øjnene. Ved adverbiet süst 'sådan' røber omlydstegnet og det epentetiske $t$ ordets tyske oprindelse, selvom sus 'således' - uden omlydstegn og $t$ - var ret almindeligt i nederlandsk i det 16. århundrede (se $W N T, s u s^{l}$ ). Dette ord er i øvrigt - bortset fra egennavnene Jürgen Harder og J.G. Röbel - det eneste ord med omlydstegn i kontrakten.

Et andet påfaldende fænomen er brugen af den tyske relativpartikel so i sætningen doch subsidien gelder, so den armen Preestern tot hulpe gegeven worden, sal de Proster sulvest erleggen 'men bistandspenge, der gives til de fattige præster, skal præsten selv betale afgift af'. De første eksempler på relativpartiklen so 'der, som'- der historisk kun kan forekomme som subjekt og direkte objekt - stammer fra 1100-tallet, men de fleste hører hjemme i højbarokken (mellem 1630/50 og 1700/20), dvs. i den tid, kontrakten blev affattet (jf. Behaghel 1928, 730; Ágel (i trykken), 3). Relativpartiklen so brugtes overregionalt og var tendentielt forbundet med kancellisproget og den højere diskurstradition (Brooks 2006, 135). Samme relativpartikel forekommer i øvrigt også i vedtægten i alle de jenige so up Dragöe wohnhaft sind 'alle dem, der bor på Dragør' (Winge 1992, 342).

Den mest overraskende tyske indflydelse vedrører imidlertid kasusbrugen. Hvad det talte sprog angår, kan det nævnes, at de tidligste nederlandske kolonisters modersmål ikke havde et fungerende kasussystem 
mere, eftersom nominativ og akkusativ var faldet sammen (synkretisme), og dativ og genitiv - på nær nogle få uproduktive levn - var så godt som forsvundet fra nederlandsk i 1500-tallet (Crena de Iongh 1959, 94; De Korne \& Rinkel 1987, 31; Geerts 1966, 171; Van den Toorn e.a. 1997, 300). Hvis teksten fremviser et fungerende kasussystem, kan dette således i hvert fald ikke stamme fra de tidligste kolonisters (talte) modersmål.

For at undersøge kasusbrugen skal man først og fremmest identificere de forskellige adnominale endelser. Til vores formål - identifikation af et funktionelt kasussystem - er det tilstrækkeligt at se på pronominers endelser og adjektivers stærke endelser. Traditionelt skelnes mellem funktionel kasus (dvs. kasus i nominativisk, akkusativisk, dativisk og genitivisk funktion) og præpositional kasus (dvs. kasus styret af en præposition). Først identificeres de adnominale stærke endelser i funktionel kasus, derefter i præpositional kasus.

I teksten forekommer nominativisk funktion i 10 tilfælde:

(1) Wanneer (...) Syne koninglyke Majestet (...) Schatt opleydt.

Når Hans Kongelige Majestæt pålægger en beskatning.

(2) So sal de Kerke (...) uthleggen.

Så skal kirken udlægge.

(3) Subsidien gelder (...) sal de Proester sulvest erleggen.

Bistandspenge skal præsten selv betale afgift af.

(4) Daer de Kerke (...) sowel geven moeste als de Preester.

Til hvilken både kirken og præsten skulle afdrage.

(5) Daer de Kerke (...) sowel geven moeste als de Preester.

Til hvilken både kirken og præsten skulle afdrage.

(6) Wanneer de Kerke (...) mede schatten sal.

Når kirken skal medbetale.

(7) De Prcester sal selven (...) geven.

Præsten skal selv give.

(8) Insgelyken is de Kerke (...) schuldig (...) te verschaffen.

Ligeledes bør kirken give.

(9) De oorsake (...) zyn dese.

Årsagen er følgende.

(10) Terwyl de Preester (...) niet heeft akker of enge.

Fordi præsten hverken har ager eller eng.

I alle disse tilfælde er der tale om subjektsfunktion. Både i maskulinum $(3,5,7,10)$, femininum $(1,2,4,6,8)$ og pluralis $(9)$ bruges endelsen $-e$. 
Akkusativisk funktion forekommer i 5 tilfælde:

(11) So sal de Kerke (...) alle schatting (...) uthleggen. Så skal kirken udlægge al skat.

(12) So sal (de Kerke) dem Præster niet meer als de halve part (...) tot hulpe komen.

Så skal kirken ikke hjælpe præsten med mere end halvdelen.

(13) De Præster sal selven de andere halve part (...) geven.

Præsten skal selv give den anden halvdel.

(14) De Kerke (is) schuldig dem Preester een Vrywoonhuys (...) te verschaffen.

Kirken bør give præsten fri bolig.

(15) Insgelyken (heeft de Preester) geene Tiende vam Veh.

Ligeledes har præsten ingen tiende for kvæg.

I alle disse tilfælde er der tale om direkte objektfunktion. Både i femininum $(11,12,13)$ og pluralis (15) bruges endelsen -e. Den ubestemte artikel een (14) i neutrum singularis har ingen endelse. Desværre er der ingen eksempler på maskulinum singularis. I nominativisk funktion bruges således konsekvent endelsen $-e$, medens vi ikke ved, om endelsen $-n$ bruges i akkusativisk funktion.

Dativisk funktion forekommer i 5 tilfælde:

(16) Wanneer (...) Syne koninglyke Majestet den Prcestern (...) Schatt opleydt.

Når Hans Kongelige Majestæt pålægger præsterne en beskatning.

(17) Subsidien gelder, so den armen Preestern (...) gegeven worden.

Bistandspenge, der gives til de fattige præster.

(18) So sal (de Kerke) dem Prcester (...) tot hulpe komen.

Så skal kirken hjælpe præsten.

(19) Insgelyken is de Kerke (...) schuldig dem Preester een Vrywoonhuys en Residence te verschaffen.

Ligeledes bør kirken give præsten frit hus og bopæl.

(20) Als süst (...) dem Preestern nae der ordinantie gebeurt.

Som dette sker for præsterne ifølge (kongeligt) dekret.

I alle disse tilfælde er der tale om indirekte objektfunktion. I maskulinum singularis $(18,19)$ bruges $-m$, i pluralis $(16,17,20)$ både $-m$ og $-n$. Endelsen $-m$ og markeringen af dativ pluralis ved substantiverne med $-n$ er tysk og 
ikke nederlandsk. I modsætning til tysk bruges $-m$ dog også i pluralis, nemlig i variation med $-n$. Denne variation er ikke fonologisk betinget, eftersom eksemplerne (16) og (20) viser, at både $-n$ og $-m$ kan forekomme foran samme konsonant.

Genitivisk funktion forekommer i fire tilfælde:

(21) wegens der Princessinnen Stuyr

på grund af prinsessestyren

(22) uyt der Kerken rekeninge

af kirkeregnskabet

(23) uthlegginge aller koninglyke schatting

betaling af al kongelig skat

(24) tot getuygenisse der Waerheit

som vidnesbyrd for sandheden

Eksemplerne (23) og (24) er utvetydige. Her er der tale om genitiviske attributter med endelsen $-r$ i femininum singularis. Derimod er eksemplerne (21) og (22) tvetydige: der Princessinnen (21) og der Kerken (22) kan ses som genitiviske attributter til henholdsvis Stuyr (21) og rekeninge (22) med endelsen $-r$ i henholdsvis pluralis og femininum singularis, men samtidig kan Princessinnen Stuyr (21) og Kerken rekeninge (22) også ses som ikke-sammenskrevne sammensætninger. I dette tilfælde står den ikke-sammenskrevne sammensætning Princessinnen Stuyr (21) i genitiv (femininum singularis) på grund af præpositionen wegens, der styrer genitiv, og den ikke-sammenskrevne sammensætning Kerken rekeninge (22) står i dativ (femininum singularis) på grund af præpositionen $u y t$, der styrer dativ.

De endelser, der findes i de ovenstående eksempler, kan gengives i følgende paradigme (med forbehold for tvetydigheden ved eksemplerne (21) og (22)):

\begin{tabular}{|c|c|c|c|c|}
\hline & \multicolumn{3}{|c|}{ Singularis } & pluralis \\
\cline { 2 - 5 } & maskulinum & femininum & neutrum & $\mathrm{m} . / \mathrm{f} . / \mathrm{n}$. \\
\hline $\mathrm{N}$ & $-e$ & $-e$ & - & $-e$ \\
\hline $\mathrm{A}$ & - & $-e$ & - & $-e$ \\
\hline $\mathrm{D}$ & $-m$ & $(-r)$ & - & $-n,-m$ \\
\hline $\mathrm{G}$ & - & $-r$ & - & $(-r)$ \\
\hline
\end{tabular}

Fig 2: Adnominale stærke fleksionsendelser ved funktionel kasus 
Desuden findes i teksten følgende præpositionalfraser:

(25) tusschen den Preester mellem præsten

(26) (tusschen) den Schout mellem oldermanden

(27) (tusschen) syne drie jaars Scheepen mellem hans tre års meddomsmænd

(28) in voller (contract) i fuld kontrakt

(29) (in) vaster contract i fast kontrakt

(30) om den Preester Schatt om præsteskatten

(31) im Lande i landet

(32) voor den Preester for præsten

(33) in desen jaer $i$ år

(34) van haere Tienden af sin tiende

(35) van haeren egen Tienden af sin egen tiende

(36) tot synen schatt til hans skat

(37) van synen schatt af hans skat

(38) nae ouden gebruyk efter gammel skik

(39) van dese twee laeste posten til disse sidste to poster

(40) aan dese plaetse her på stedet

(41) by synen deenste for sin embedsgerning

(42) vam Veh af kvæg 
(43) im gantzem Ryke

$i$ hele riget

(44) nae der ordinantie

ifølge kongeligt dekret

(45) van de Gemeente

af kommunen

(46) van allem ouden tyd her

for længe siden

(47) uyt het Kerken-Rekeninge-boek

fra kirkeregnskabsbogen

Historisk set styrer præpositionerne by, nae, tot, uyt og van dativ (jf. nyhøjtysk bei, nach, zu, aus og von), medens om styrer akkusativ (jf. nyhøjtysk um), og aan, in, tusschen og voor både dativ og akkusativ (jf. nyhøjtysk an, in, zwischen og vor).

Præpositioner, der historisk styrer dativ, styrer i kontraktteksten dog både dativ og akkusativ. Præpositionen van styrer f.eks. akkusativ i van de Gemeente (45), van haere Tienden (34) og van dese twee laeste posten (39), men dativ i van haeren egen Tienden (35), vam Veh (42) og van allem ouden tyd her (46). Også i andre tilfælde optræder akkusativ, hvor der forventes dativ, f.eks. i (tusschen) syne drie jaars Scheepen (27), aan dese plaetse (40) eller uyt het Kerken-Rekeninge-boek (47). Vi kan med andre ord gå ud fra, at akkusativ og dativ ikke optræder systematisk efter præpositioner, der historisk styrer akkusativ og/eller dativ. Efter disse præpositioner konkurrerer $-n(25,26,30,32,36,37,41)$ og $-m(46) \mathrm{i}$ maskulinum singularis, $-e(40,45)$ og $-r(28,29,44)$ i femininum singularis, $-n(33,38),-m(42,43)$ og $-t(47)$ i neutrum singularis, og $-n(35)$ og $-e$ $(27,34,39)$ i pluralis. Desuden viser en sammenligning mellem van haeren egen Tienden (35) og van allem ouden tyd her (46), at variationen mellem $-n$ og $-m$ ikke er fonologisk betinget, eftersom begge endelser forekommer foran vokal.

De fleksionsendelser, der findes i de ovenstående eksempler, kan gengives i følgende paradigme:

\begin{tabular}{|l|l|l|l|l|}
\hline $\begin{array}{l}\text { Præpositioner } \\
\text { med A/D }\end{array}$ & $-n,-m$ & $-e,-r$ & $-t,-n,-m$ & $-e,-n$ \\
\hline
\end{tabular}

Fig 3: Adnominale stærke fleksionsendelser ved præpositionel kasus 
Med udgangspunkt i en syntese mellem fig. 2 og 3 kan følgende paradigme opstilles:

\begin{tabular}{|c|c|c|c|c|}
\hline & \multicolumn{3}{|c|}{ Singularis } & pluralis \\
\cline { 2 - 5 } & maskulinum & femininum & neutrum & $\mathrm{m} . / \mathrm{f} . / \mathrm{n}$. \\
\hline $\mathrm{N}$ & $-e$ & $-e$ & $-*^{*} t$ & $-e$ \\
\hline $\mathrm{A}$ & $-*_{n}$ & $-e$ & $-t$ & $-e$ \\
\hline $\mathrm{D}$ & $-n,-m$ & $-r$ & $-n,-m$ & $-n,-m$ \\
\hline $\mathrm{G}$ & $-*_{s}$ & $-r$ & $-*_{s}$ & $-r$ \\
\hline
\end{tabular}

Fig. 4: Adnominale stærke fleksionsendelser ved funktionel og præpositionel kasus

Asterisken angiver, at de respektive endelser ikke forefindes i selve teksten. Til gengæld kan de let rekonstrueres. Eftersom endelsen - $t$ forekommer efter præposition i akkusativ neutrum singularis (47), kan man gå ud fra, at $-t$ også er endelsen i nominativ neutrum singularis. Det stemmer også overens med den pronominale endelse $-t$ i ' $\underline{t} z y$ 'medmindre, højtysk: es sei (denn)'; wat name 't ook hebben mag 'hvad det så end måtte hedde'; is 't so veraccordeert 'blev det aftalt'; og is 't hem (...) belooft 'er det blevet lovet ham'. Endelsen $-n$ i akkusativ maskulinum singularis er ligeledes let at rekonstruere, eftersom der ingen historiske forskelle er mellem nederlandsk og tysk på dette punkt. Det samme gælder endelsen $-s$ i genitiv maskulinum og neutrum singularis.

Nøglen til forståelsen af kasusparadigmet er imidlertid den særlige dativbøjning. I kontrakten konkurrerer den tyske dativendelse $-m$ frit med den (historiske) nederlandske dativendelse $-n$, der dog $-\mathrm{i}$ talesproget - kun eksisterede i uproduktive levn, da kolonisterne slog sig ned på Amager. Dette lader formode, at amagerhollænderne i deres skriftsprog har udviklet et nyt kasussystem med forbillede i tysk. Resultatet er et selvstændigt kasussystem, der hverken set fra et tysk perspektiv eller fra et (historisk) nederlandsk perspektiv er grammatisk. Set med tyske øjne er den adnominale endelse - $m$ ikke grammatisk i pluralis (jf. Lasch 1914, 102), og set med (historisk) nederlandske øjne er hverken den adnominale endelse - $m$ i maskulinum og neutrum singularis og pluralis eller den nominale endelse $-n$ i pluralis grammatisk (jf. Van Loey 1976, 27-32). Imidlertid kunne udviklingen af dette kasussystem kun ske hos sprogbrugere, der havde et omfattende kendskab til tysk bøjningsmorfologi. 
Ironisk nok har amagerhollændere hermed opnået, hvad de nederlandske renæssancefilologer drømte om, men ikke kunne opnå: en genoprettelse af kasussystemet - $\mathrm{i}$ hvert fald i skriftsproget - efter tysk forbillede, der kunne konkurrere med det græske og det latinske. Det var f.eks. et af de vigtigste formål med den første nederlandske grammatik, Hendrik Laurensz Spiegels (1549-1612) Twe-spraack van de Nederduitsche letterkunst, der udkom i Leiden i 1584.

\section{En sammenligning}

Winge (1992, 342-243) bestemte vedtægtens sprog som hovedsageligt nedertysk med højtyske ortografiske og leksikale træk (deriblandt også funktionsordene welche, unsere [ved siden af nedertysk unse] og jeder), medens de danske træk var rent ortografiske. Desuden fandtes i teksten nogle få 'nederlandske relikter'.

Analysen af kontraktens sprog i nærværende studie vender Winges konklusion på hovedet. I modsætning til vedtægtens sprog er kontraktens sprog gennemgående nederlandsk med en begrænset ortografisk og leksikal neder- og højtysk andel samt en meget begrænset ortografisk og leksikal dansk andel. Den store overraskelse - set med nederlandske øjne - er dog forekomsten af et fungerende kasussystem efter tysk forbillede.

Det betyder, at analysen af vedtægten fra 1663 og kontrakten fra 1664 leder frem til to modsatte bestemmelser af amagerhollændernes skriftsprog i 1600-tallet: dels som 'hovedsageligt nedertysk med en mindre nederlandsk andel', dels som 'hovedsageligt nederlandsk med en mindre nedertysk andel'.

\section{En hypotese}

Disse to modsigende bestemmelser af amagerhollændernes skriftsprog kan dog forenes ved, at man betragter sproget fra et synkront variationsperspektiv. Min hypotese er således, at amagerhollændernes skriftsprog omkring 1663/64 er karakteriseret ved et nederlandsk-nedertysk kontinuum. Til interne dokumenter (inden for Store Magleby) brugte man et sprog, der kan bestemmes som nederlandsk med nedertysk islæt, medens man til eksterne dokumenter (f.eks. mellem Store Magleby og Dragør) brugte et nedertysk, der var så rent som muligt, og som i denne periode fungerede som lingua franca i hele Østersøområdet. Inden for dette kontinuum spiller kasussystemet en afgørende rolle, idet dette adskiller de nederlandske kolonisters skriftsprog både fra nederlandsk og nedertysk. 
Den kommunikative kontekst definerer således sprogforholdene inden for det nederlandsk-nedertyske kontinuum: Kontrakten fra 1664 mellem præsten og oldermanden tjener et internt formål, Til gengæld tjener vedtægten et eksternt formål, idet den skal regulere forholdene mellem Store Magleby og nabobyen Dragør. Også indskrifterne tjener et eksternt formål, idet de taler til besøgende udefra. Sproget i vedtægten og indskrifterne skal således forstås som forsøg på et skrive et nedertysk, der er så rent som muligt. Set på den måde er det næsten ironisk, at Pontoppidan (og derefter de Thurah) brugte vedtægten som skoleeksempel på 'amagerhollandsk', da vedtægtens sprog snarere repræsenterer et yderpunkt i kontinuummet, nemlig det punkt, der befinder sig længst væk fra nederlandsk og tættest på nedertysk.

Forhåbentligt vil en omfattende undersøgelse af flere tekster gøre det muligt at drage endnu mere præcise konklusioner om de nederlandske kolonisters skriftsprog på Amager og dettes udvikling.

\section{Litteratur}

Ágel, Vilmos (i trykken): +/- Wandel. Am Beispiel der Relativpartikeln so und wo. I Dagmar \& Livio Gaeta (red.), Das ewige Pendel von synthetisch zu analytisch zu synthetisch - aktuelle Sprachwandeltendenzen im Deutschen. Berlin/New York: de Gruyter.

Appel, Charlotte. 2001. Lasning og bogmarked i 1600-tallets Danmark (Danish Humanist Texts and Studies 23). 2 bind. København: Det Kongelige Bibliotek og Museum Tusculanums Forlag.

Behaghel, Otto. 1928. Deutsche Syntax. Eine geschichtliche Darstellung (Germanistische Bibliothek, Abt. Sammlung germanischer Elementar- und Handbücher, Grammatiken 10). Bind 3. Heidelberg: Winter.

Berteloot, Amand. 1984. Bijdrage tot een klankatlas van het dertiende-eeuwse Middelnederlands. I. Tekst, II. Platen. Gent: Academie voor Nederlandse Taal en Letterkunde.

Brooks, Thomas. 2006. Untersuchungen zur Syntax in oberdeutschen Drucken des 16.-18. Jahrhunderts (Schriften zur deutschen Sprache in Österreich 36). Frankfurt am Main etc.: Lang.

Crena de Iongh, Adrianus Cornelis. 1959. G. van Santen's Lichte Wigger en Sanppende Siitgen. Zeventiende eeuwse gesprekken in Delfts dialect. Assen: Van Gorcum \& Comp. 
Encyklopcedien $=$ Den Store Danske Encyklopcedi. København: Danmarks Nationalleksikon A/S. 1994-2001, 2002 (supplementsbind 1), 2003 (2 indeksbind), 2004 (cd-rom-version), 2006 (supplementsbind 2).

Geerts, Guido. 1966. Genus en geslacht in de Gouden Eeuw. Bruxelles: Belgisch Interuniversitair Centrum voor Neerlandistiek.

Harder, Thomas. 1715. Nedder-Düdesche Kercken und Huß Psalm-Boeck, Tho deenst der Holländer Gemeene up Amack in Drück gestellet, vormehret, und in Ordeninge gebracht. København: J.J. Höpffner.

Kalkar, Otto. 1892-1901. Ordbog til det celdre danske Sprog (1300-1700). 5 bind. København: Thieles Bogtrykkeri.

Korne, Annet de \& Tineke Rinkel. 1987. Cursus zestiende- en zeventiende-eeuws Nederlands. Groningen: Wolters-Noordhoff.

Lasch, Agathe. 1914. Mittelniederdeutsche Grammatik. Halle: Niemeyer.

Loey, Adolphe van. 1970. Schönfeld's Historische Grammatica van het Nederlands. Zutphen: W.J. Thieme.

Loey, Adolphe van. 1976. Middelnederlandse spraakkunst. Deel I. Vormleer. 8. udgave. Kapellen: De Sikkel.

Loey, Adolphe van. 1980. Middelnederlandse spraakkunst. Deel II. Klankleer. 8. udgave. Kapellen: De Sikkel.

Nicolaisen, Christian. 1907-1909-1915. Amagers historie. Bilagt med de vigtigste breve og arkivstykker om øens forhold. København: Schous Forlag. 3 bind.

ODS = Ordbog over det danske Sprog. København 1918-2005: https://ordnet.dk/ ods/ (2. september, 2019.)

Pedersen, Axel. 1968. Birketing $i$ Gl. Københavns Amt 1521-1965. København: Juristforbundet.

Pontoppidan, Erik. 1757. Kort efterretning om nogle Coloniers eller fremmede Folks Ankomst og Forplantelse her i Dannemark særdeles først om Amagerne og flere fra Nederlandene her ankomne. I Pontoppidan, Skrifter, som udi det Kiøbenhavnske Selskab af Lordoms og Videnskabers Elskere ere fremlagte og oplceste. København, 121-146.

Rasmussen, Anna William. 1968. Hollcenderbyen og Store Magleby Kirke. København: Kristeligt Dagblad.

Riber, Hermann Regner. 1975. Hollcenderbyens Bomcerker. St. Maglebys gårde, deres indretning og ejerforhold. Kastrup: Kastrup Central Forlag.

Skautrup, Peter. 1947. Det danske sprogs historie. 4 bind. København: Gyldendal. Spiegel, Hendrik Laurensz. 1584. Twe-spraack vande Nederduitsche letterkunst. Leiden: Christoffel Plantyn.

Thurah, Laurits de. 1758. Omstcendelig og tilforladelig Beskrivelse over den liden Øe Amager og den ei langt derfra situerede endnu mindre Øe Saltholm. København: Nicolaus Møller. 
Toorn, Maarten Cornelis van den, Willy Pijnenburg, Jan van Leuvensteijn \& Joop van der Horst. 1997. Geschiedenis van de Nederlandse taal. Amsterdam: Amsterdam University Press.

Winge, Vibeke. 1992. Dänische Deutsche - deutsche Dänen. Geschichte der deutschen Sprache in Dänemark 1300-1800 mit einem Ausblick auf das 19. Jahrhundert. Heidelberg: Winter.

Winge, Vibeke. 2001. Laat Deen en Noor met Eerbied u begroeten. Niederländer und Niederländisch in Dänemark. Ein Überblick. I Robert Peters \& Hubertus Menke (red.), Vulpis Adolatio: Festschrift für Hubertus Menke zum 60. Geburtstag. Heidelberg: Winter. 299-307.

$W N T=$ Woordenboek der Nederlandsche Taal. 1864-1998: https://ivdnt.org/ onderzoek-a-onderwijs/lexicologie-a-lexicografie/wnt (2. september, 2017.)

Bilag 1: Pontoppidans transskription af vedtcegten mellem Store Magleby og nabobyen Dragør fra 3. december 1663

Anno 1663. Donnertages den 3 Decembr. dat Recht geholden van Schultes Didrich Cornelesen und de gemene Schepens namentlig Jacob Clausen und Didrich Weibrandsen. De sölwen Dages heft Schultes Didrich Cornelesen alle Indvaaners op Dragöer vor et Rath stevnen laten, unde wegen de vorige Contract so ere Vorfahren mit unse Vorælders heben gemacht unde ingegangen, efte si dörbi wollen bliwen, hier na als si toforn heben gedan, welche Contract in det vorgangne Krigs Wæsen unde Fürs-Noth is to nichte geworden. To welcher Citatorschrevne Dragöers Lüde alle samtlich vor it Rath sind gemöttet, und hebben dar to geantwortet, dat se bi ere vorige Contract wolten bliwen herna als se toforne gedan hetten, welcher Indhaldt also lüttet: 1) Vor het erste, wat se den Præster schöllen gewen vor sin Denst, dat he se underricht in de Kirche. 2) Dat se nemand van unse Gemeende ut er Kirchestule sollen drengen. 3) Dat se vor ein olde dode Schöllen gewen, der hier in et Kirchhoff begraben wird 8 Schill. und vor ein Kind 4 Schill. 4) Dat se nemand van unse Gemeende schöllen uddrengen, even dar ein Schip an de Grond komt unde nemand van unsere schölen de Dragöer Lüde ud drengen. 5) Dat se belowet hebben, vor jeder paar Perde dat se hier op se Weide hebben, to gebben 2 Rixdal. 6) Und ein Kühe ein Schlechdaler. 7) Vor ein Færken 4 Schill. unde er Færkens to ringen, nach de Königs Mandat, als behörigist [= behörig ist, JR]. 8) Dat alle de jenige so up Dragöe wohnhaft sind, unde Perde unde Wagens hebben, schölen to Brig Geld gewen jærlig jederman 4 Schill. unde de dar Perde und Wagens hebben schölen gewen gelich mit uns hier in Dörp. 9) Dat se de Bosmand schölen lehnen wen der Udschrift falt gelich alse ere Vorfahren gedan hebben. 10) Wen der Königs Schatt upkomt in de Stede vor de Königs Schatt, dat se vor 4 Höffe schollen gewen, gelich als ere Vorfahren alle Tidt hebben gedan. 11) Dat se den Schout schölen anspreken um Vorlof wanneer dat se kley efte sade van unse Wide nödig hebben. dert Dat dit in der Wahrheit ende unwiderröplik 
van uns ende unse Nachkömlinge schal geholden werden wo bowen vermeldt, hebben wi nachgeschribenen Mons Nielsen, Christen Nielsen, Thomas Mathiesen, Piter Hendrichsen, Palm Hendrichsen, Peter Asmussen, Joen Svendsen und Söeren Paulsen up de gemene Dragöer Manne wegen, dat met unse egen Hande efte Boemerke bekræftiget unde undergeskreven up Amak im Hollænder dorpe geschrewen Jar und Dag wo bowen vermeldt. 